\title{
Influence of time of concentrate feeding to sheep on diurnal pattern of intake and digestion of hay
}

\author{
M. D. Carrot, A. R. Mantecónł, I. A. Wright and I. J. Gordon \\ Macaulay Land Use Research Institute, Craigiebuckler, Aberdeen AB9 2QJ
}

\section{Introduction}

The rôle of supplementary feeding of sheep in most hill and upland sheep systems is well recognized in supplying extra nutrients and in influencing resource management (Milne and Mayes, 1986). Mechanisms regulating grazing behaviour are modified during supplementary feeding and the time of supplementary feeding may affect the diurnal pattern of herbage intake. In supplement feeding studies grazing complicates interpretation because forage quality continually changes; therefore, most of these studies have been conducted with harvested rather than grazed forage.

The aim of this experiment was to evaluate if the time of supplementary feeding has any influence on the voluntary intake of a basal grass hay diet and on its diurnal pattern of intake.

\section{Material and methods}

The experiment was conducted with 12 Blackface wethers averaging 53.9 (s.e. 6.70) $\mathrm{kg}$ live weight, which were divided into two groups (A and $M$ ), according to live weight and body condition. Hay was offered ad libitum to all animals through the experiment from 08.30 to $09.30 \mathrm{~h}$ and from 16.30 to $08.30 \mathrm{~h}$, in order to promote a high rate of intake in the morning and late afternoon.

After a 3-week period (period 1), half the animals were offered concentrate $(700 \mathrm{~g} /$ day $)$ at $09.30 \mathrm{~h}$ (group M) and the other half at $16.00 \mathrm{~h}$ (group A) for a further period of 3 weeks (period 2). The chemical composition of the hay and concentrate is shown in Table 1. In each period, voluntary intake of hay was measured for 10 days, during which hay was offered at proportionately 1.10 to 1.15 in excess of the previous day's consumption. Pattern of hay intake was measured by weighing refusals every $3 \mathrm{~h}$ on 2 days consecutively. In order to measure the digestibility, a total collection of faeces was made for

Present addresses:

+ University of León, 24007 León, Spain.

‡ Estación Agrícola Experimental, CSIC, Apartado 788, 24080 León, Spain. the last 8 days of each experimental period, during which the sheep were harnessed and equipped with collection bags. Rumen fluid samples were obtained on the last day of each experimental period at 12.00 , $18.00,24.00$ and $06.00 \mathrm{~h}$ using a stomach tube and $\mathrm{pH}$, volatile fatty acids (VFA) and ammonia concentrations were determined.

Data were analysed according to a $2 \times 2$ factorial analysis of variance with sheep as a blocking factor (Statistical Analysis System Institute, 1985). Effects included in the model were concentrate supplementation (CS), time of supplementation (TS) and the interaction CS $\times$ TS, and additionally for the fermentation measurements the time of sampling.

\section{Results and discussion}

When concentrate was offered in the morning the daily pattern of hay intake was not changed (Table 2) and animals had the highest rate of intake (about 0.39 of the daily intake) between 16.30 and $18.00 \mathrm{~h}$. However, when animals were offered the concentrate in the afternoon the rate of hay intake was lowered between 16.30 and $18.00 \mathrm{~h}$ (about 0.25 of the daily intake). It may be due to the high ruminal digesta fill in this period (animals consumed $700 \mathrm{~g}$ concentrate within $15 \mathrm{~min}$ of feeding) and, as consequence, wethers were not able to have a high intake of hay.

In all, animals given concentrate in the morning had a higher $(P<0.05)$ intake of hay organic matter and higher $(P<0.01)$ rumen ammonia levels than those given concentrate in the afternoon (Table 3). However, there were no differences in the digestibility of the diet, rumen $\mathrm{pH}$ and molar proportions of the main VFA.

Table 1 Chemical composition ( $g / k g$ dry matter) of grass hay and concentrate

\begin{tabular}{lcc}
\hline \hline & Hay & Concentrate \\
\hline Crude protein & 105 & 235 \\
Neutral-detergent fibre & 626 & 267 \\
Acid-detergent fibre & 386 & 135 \\
\hline \hline
\end{tabular}


Table 2 Effect of concentrate supplementation (CS) and time of supplementation (TS) on pattern of hay intake ( $\mathrm{g}$ dry matter per day)

\begin{tabular}{|c|c|c|c|c|c|c|c|c|}
\hline \multirow[b]{2}{*}{ Group } & \multicolumn{2}{|c|}{ Hay } & \multicolumn{2}{|c|}{ Hay + supplement } & \multirow{2}{*}{$\begin{array}{c}\text { Residual } \\
\text { s.d. }\end{array}$} & \multicolumn{3}{|c|}{ Significance of } \\
\hline & M & A & $\mathrm{M}$ & A & & CS & TS & $\mathrm{CS} \times \mathrm{TS}$ \\
\hline \multicolumn{9}{|l|}{ Time } \\
\hline $16.30-18.00$ & 589 & 511 & $542^{a}$ & $271^{b}$ & 139 & $* * *$ & $* * *$ & * \\
\hline $18.00-21.00$ & 207 & 180 & 233 & 191 & 70.7 & & & \\
\hline $21.00-24.00$ & 164 & 185 & 144 & 142 & $54 \cdot 3$ & * & & \\
\hline $24.00-03.00$ & 129 & 135 & 117 & 148 & $45 \cdot 5$ & & & \\
\hline $03.00-06.00$ & 89 & 109 & 92 & 82 & $41 \cdot 2$ & & & \\
\hline $06.00-08.30$ & 73 & 86 & 66 & 84 & $34 \cdot 2$ & & & \\
\hline $08.30-09.30$ & 199 & 181 & 112 & 103 & $62 \cdot 5$ & * & & \\
\hline
\end{tabular}

a,b Means within each treatment in the same line with different superscripts differ significantly $(P<0 \cdot 05)$.

Table 3 Effect of concentrate supplementation (CS) and time of supplementation (TS) on voluntary intake of hay, apparent digestibility and rumen parameters ( $\mathrm{pH}$, ammonia-N $(\mathrm{mg} / \mathrm{l})$ and VFA ( $\mathrm{mol} / 100 \mathrm{~mol})$ )

\begin{tabular}{|c|c|c|c|c|c|c|c|c|}
\hline \multirow[b]{2}{*}{ Group } & \multicolumn{2}{|c|}{ Hay } & \multicolumn{2}{|c|}{ Hay + supplement } & \multirow{2}{*}{$\begin{array}{l}\text { Residual } \\
\text { s.d. }\end{array}$} & \multicolumn{3}{|c|}{ Significance of } \\
\hline & M & A & M & A & & CS & TS & $\mathrm{CS} \times \mathrm{TS}$ \\
\hline \multicolumn{9}{|l|}{ Hay intake (g/day) } \\
\hline Organic matter & 1044 & 1007 & $871^{\mathrm{a}}$ & $674^{b}$ & $167 \cdot 2$ & ** & & \\
\hline \multicolumn{9}{|l|}{ Apparent digestibility } \\
\hline Organic matter & 0.685 & 0.686 & 0.712 & $0-696$ & 0.0261 & & & \\
\hline Crude protein & 0.644 & 0.656 & 0.708 & 0.702 & 0.0267 & $* * *$ & & \\
\hline Acid-detergent fibre & $0 \cdot 653$ & $0 \cdot 658$ & $0 \cdot 631$ & $0 \cdot 606$ & 0.0372 & * & & \\
\hline \multicolumn{9}{|l|}{ Rumen parameters } \\
\hline $\mathrm{pH}$ & $7 \cdot 02$ & $7 \cdot 06$ & $7 \cdot 03$ & $7 \cdot 02$ & 0.183 & & & \\
\hline Ammonia- $\mathrm{N}$ & 69.2 & $63 \cdot 19$ & $148^{\mathrm{a}}$ & $123^{\mathrm{b}}$ & $22 \cdot 27$ & $* * *$ & $* * *$ & * \\
\hline Acetate & $65 \cdot 0^{\mathrm{a}}$ & $66 \cdot 8^{b}$ & $71 \cdot 4$ & $70 \cdot 4$ & 2.59 & $* * *$ & & * \\
\hline Propionate & $23 \cdot 4^{a}$ & $22 \cdot 0^{\mathrm{b}}$ & $16 \cdot 9$ & $17 \cdot 5$ & $2 \cdot 03$ & $* * *$ & & * \\
\hline Butyrate & $9 \cdot 13$ & $8 \cdot 74$ & 9.23 & 9.47 & 1.193 & & & \\
\hline
\end{tabular}

a, b Means within each treatment in the same line with different superscripts differ significantly $(P<0 \cdot 05)$.

\section{Conclusions}

Feeding concentrate in the morning instead of in the afternoon resulted in a higher $(P<0.05)$ total intake (881 and $1041 \mathrm{~g}$ digestible organic matter per day) for the $A$ and $M$ groups, respectively.

\section{References}

Milne, J. A. and Mayes, R. W. 1986. Supplementary feeding and herbage intake. Hill Farming Research Organisation, Biennial Report 1984-1985, pp. 115-119.

Statistical Analysis System Institute. 1985. User's glide: statistics. Statistical Analysis Systems Institute, Cary, NC. 